\title{
Physiological response of the blue shrimp Litopenaeus stylirostris to short-term confinement on a pond bottom
}

\author{
Chantal Mugnier*, Hugues Lemonnier and Alexandre Legrand
}

Laboratoire d'Aquaculture Calédonien, IFREMER, BP2059, 98846 Nouméa Cedex, New Caledonia

*: Corresponding author : Tel.: +687 3525 71; fax: +687 2878 57. cmugnier@ifremer.fr

\begin{abstract}
The blue shrimp Litopenaeus stylirostris was exposed to pond sediment for $48 \mathrm{~h}$ and its physiological response was studied in relation to molt stage. Shrimp were maintained in cages within a semi-intensive pond after 4 months of rearing. Hypo-osmoregulatory capacity (hypo-OC), magnesium ions ( $\mathrm{Mg}$ ions), glucose, total proteins and oxyhaemocyanin were assayed in haemolymph. An increase of $370 \%$ to $500 \%$ in $\mathrm{Mg}$ ions concentration and $200 \%$ to $266 \%$ in glucose concentration, and a decrease in hypo-OC in shrimp maintained close to the centre of the pond indicated a short-term stress response in all molt stages. Indicators of water and sediment pore water quality were within normal operating limits, however this area was characterized by high water content and relatively high total ammonia nitrogen in pore water of sediment. To a lesser extent, shrimp maintained in two other stations also presented a stress response. Physiological response of shrimp in molt stage D1 compared to C/D0 and D2 seems to indicate that shrimp were more sensitive to environment at this stage. The use and choice of physiological parameters to detect shrimp stress in a pond are discussed.
\end{abstract}

Keywords: Litopenaeus stylirostris; Haemolymph constituents; Molt stage; Penaeid shrimp; Pond bottom; Stress 


\section{Introduction}

Shrimp farming in New Caledonia is an economically important developing industry. It is based on the culture of the blue shrimp L. stylirostris, reared in earthen ponds. Shrimp spend much of their time on the bottom of the ponds, so soil quality is an important component of the pond ecosystem for the shrimp (Boyd, 1995). Delgado et al. (2003) found that shrimp abundance was significantly lower in the zone where sludge depth and organic matter accumulation were higher, suggesting conditions may have been less suitable for shrimp growth and health. Moreover, Ritvo et al. (1998) demonstrated the impact of the type of soil on the growth of the shrimp Penaeus vannamei, independently of the quality of the inflow water. Reduced feeding, slower growth (Ram et al., 1982; Avnimelech and Zohar, 1986), and low survival (Hopkins et al., 1994; Lemonnier and Brizard, 2001) have also been related to soil chemistry.

While health state and physiological response of shrimp in controlled experimental tanks is commonly studied, the state of shrimp reared in pond has scarcely been evaluated, probably because of the uncontrolled environmental parameters encountered in a pond ecosystem. However, Lignot et al. (1999) were able to record the evolution of glycemia and osmolality in L. stylirostris reared in earthen pond over 24h, and show a difference between starved and fed animals. Recently, results of a field experiment have shown that the $\mathrm{pH}$ of pond sediment is able to affect osmoregulation in L. stylirostris (Lemonnier et al., 2004).

The aim of this work was to study the physiology of the blue shrimp L. stylirostris in contact with pond bottom and evaluate physiological indicators of stress in a field experiment. Indicators of physiological -or more generally health- state of shrimp reared in pond would be useful tools to detect stress response and therefore adapt the management of the pond to be more suitable for shrimp.

Pond sediment characteristics were assessed with indicators proposed by Hussenot and Martin (1995) and Avnimelech et al. (2001) for field conditions, including water content of soil, which is related to bulk density of soil, redox potential (Eh), total ammonia nitrogen (TAN) and $\mathrm{pH}$, but also nitrites. As shrimp at pre- and postmolt stages are more sensitive to stress than intermolt animals (Wajsbrot et al., 1990; Mugnier and Justou, 2004; Mugnier and Soyez, 2005), molt stage of the shrimp was taking into account. Several physiological parameters that can be assayed from a haemolymph sample were selected for this study as indicators of 
response to an environmental stressor (Mugnier and Justou, 2004). Osmoregulation is one of the most important functions of regulation in Crustacea (Péqueux, 1995). Variation of osmoregulatory capacity (OC) was studied as a non-specific indicator commonly used for detecting physiological stresses, particularly in L. stylirostris (Lignot et al., 2000), which is a strong hypo-osmoregulator in sea water. In seawater, a decrease in hypo-OC is observed in $\underline{\mathrm{L}}$. $\underline{\text { stylirostris }}$ exposed to environmental stress (Mugnier and Justou, 2004; Lemonnier et al., 2004; Mugnier and Soyez, 2005). Magnesium ions concentration (Mg) is a good stress indicator, at least for acute stress, for $\underline{L}$. stylirostris (Mugnier and Justou, 2004) and for $\underline{\text { P. }}$ monodon (Boglio and Goarant, 1996). Increase in blood glucose is an indicator of short-term stress (Hall and Van Ham, 1998) also observed in L. stylirostris subjected to stressful concentration of ammonia (Mugnier and Justou, 2004). Increase in total proteins concentration in haemolymph is also an indicator of short-term stress in controlled conditions (Mugnier and Justou, 2004). The last indicator selected for this study was the plasmatic oxyhaemocyanin concentration, which is the main protein in the haemolymph and is implied in several functions like oxygen transport, enzymatic activities, osmoregulation or buffering (Paul and Pirow, 1997/98).

\section{Material and methods}

\subsection{Experimental animals}

The experiment took place in a private farm (Ferme Aquacole de la Ouenghi, FAO) in New Caledonia. L. stylirostris (stocking density 21 shrimp $/ \mathrm{m}^{2}$ ) had been reared in a non-aerated earthen pond of 7.5 ha for 4 months before the experiment was conducted. Twenty five percents of the water was exchanged per day. A previous study showed that the soil texture of the pond was mainly clay loam. The amount of clay increases from the upper side (water inlet) towards the lower side (water outlet), as it is generally observed in New Caledonia (unpublished data).

The mean weight of the sub-adult animals was $23.7 \pm 0.2 \mathrm{~g}(\mathrm{n}=276)$. Shrimp were quickly caught with a net in the pond and 15 shrimp were placed in wire mesh cages of $0.5 \mathrm{~m}^{2}$ $(100 \times 50 \mathrm{~cm})$, with a height of only $15 \mathrm{~cm}$ to allow a good contact of shrimp with sediment. Shrimp were fed commercial pellets. They were not fed $12 \mathrm{~h}$ before and during the sampling 
in order to avoid any variation in the physiological parameters due to food intake (Lignot et al., 1999).

\subsection{Molt stage determination}

Six molt stages were defined according to the retraction of the epithelium within setae of the antennal scale (Drach, 1939; Chan et al., 1988). Shrimp were classified as A and B for respectively the early and late postmolt stages, $C$ for intermolt and $D_{0}, D_{1}, D_{2}$ for premolt stages. $\mathrm{D}_{0}$ was the very early premolt stage, when epidermis starts to rectract. $\mathrm{D}_{2}$ was the late premolt stage prior to ecdysis, when the epidermis is at maximal retraction and it is possible to distinguish the developing seta.

\subsection{Experimental procedure}

Eighteen cages were placed three at a time at 6 different places in the pond (figure 1). Three were positioned in the middle of the pond (station 4, figure 1), and the others around the perimeter of the pond. To control soil effect, three cages were placed $30 \mathrm{~cm}$ above the bottom of the pond in mid water where the pond was $1.2 \mathrm{~m}$ deep (station 0 , figure 1). Shrimp were caught and transferred directly into the cages at t0. They were sampled $48 \mathrm{~h}$ later. Free animals were also caught at t48 in the pond close to the control cages and sampled as free control in order to check the effect of cage confinement. Haemolymph samples were rapidly collected via the ventral sinus using disposable syringes and needles and were immediately distributed as follow: A 10- $\mu$ l subsample of haemolymph was used for measurement of osmotic pressure with a Wescor osmometer. A 10- $\mu$ l subsample was diluted in $390 \mu \mathrm{l}$ of distilled water and oxyhaemocyanin absorbance was measured at $335 \mathrm{~nm}$ (characteristic of oxyhaemocyanin) using a Lightwave S1000 spectrophotometer. A 180- $\mu$ l subsample of haemolymph was mixed with $20 \mu \mathrm{l}$ of $10 \%$ sodium citrate and centrifuged $5 \mathrm{~min}$ at $800 \mathrm{~g}, 5^{\circ} \mathrm{C}$. The supernatant (plasma) was stored at $-80^{\circ} \mathrm{C}$ for further biochemical analysis.

\subsection{Plasma constituent analysis}

A $50-\mu$ l subsample of plasma was mixed with $100 \mu$ ice-cold $6 \%$ perchloric acid and centrifuged for $15 \mathrm{~min}$ at $13000 \mathrm{~g}$ for deproteinisation. The $\mathrm{pH}$ of supernatant was neutralized with $14 \mu \mathrm{l}$ of $\mathrm{KOH} 3 \mathrm{M}$ (Paterson, pers. com.). Commercial kits were used for glucose (Sigma) 
and magnesium (Biomérieux) determination. Kits were adapted to a microplate. Absorbance was read on a microplate reader (Digiscan Asys Hitech 340) and concentrations were calculated from a standard curve of substrate. Glucose was assayed on deproteneized plasma. The plasma level of total proteins was measured by the Lowry and al. (1951) technique adapted to microplate method, using bovine serum albumin (Sigma, molecular weight: 66,000 daltons) as a standard.

\subsection{Water and sediment analysis}

Temperature and oxygen concentrations in the water at the cages level were measured with an oxymeter Oxyguard in the morning when the dissolved oxygen concentration is at minimum. A sample of water was collected close to the cages for the following measurements: Salinity was measured using a refractometer; Turbidity was measured directly at $515 \mathrm{~nm}$ with a handheld turbidimeter Aquafluor ${ }^{\mathrm{TM}}$; The $\mathrm{pH}$ was measured with a $\mathrm{pH}$-meter Knick 651; Osmotic pressure of the water on each station was measured as for the haemolymph with the osmometer. Colorimetric methods were used to analyse total ammonia nitrogen (TAN) according to the methods of Koroleff (1976) adapted to seawater, and nitrite with the method of Benschneider and Robinson (1952).

The first centimetre of sediment was sampled in duplicate directly where the cages were located with a polypropylene sampling tube at the end of the experiment. $\mathrm{pH}$ and redox potential (Eh) were assessed in situ on the first centimetre according to the method described by Hussenot and Martin (1995). Eh was measured with a specific electrode (Cofralab PT5700A). The sediment water content was estimated by calculating the difference of weight before and after drying a subsample at $60^{\circ} \mathrm{C}$ for 5 days. A second subsample was centrifuged at $2000 \mathrm{~g}$ for 20 minutes and the pore water collected. TAN concentrations in the pore water were measured by the Koroleff method (1976) adapted to seawater. Ammonia $\mathrm{NH}_{3}-\mathrm{N}$ concentrations were calculated from the TAN according to the equilibrium equation of Bower and Bidwell (1978) based on the salinity, $\mathrm{pH}$ and temperature of the pore water. Nitrite concentrations were measured with the same method used for water samples.

\subsection{Data and statistical analysis}

The hypo-OC was calculated as the difference between the osmotic pressure of shrimp haemolymph and the seawater. The oxyhaemocyanin concentration was calculated using an 
extinction coefficient $\left(E^{\mathrm{mM}}{ }_{1 \mathrm{~cm}}\right)$ of 17.26 (Chen and Cheng, 1993). The ratio of oxyhaemocyanin to total proteins was calculated by dividing the concentration of oxyhaemocyanin $\left(\mathrm{mmol} . \mathrm{l}^{-1}\right)$ by that of total proteins $\left(\mathrm{mmol} . \mathrm{l}^{-1}\right)$, which was converted from mg.ml ${ }^{-1}$ to mmol. $\mathrm{l}^{-1}$ by dividing by 66 (Chen and Cheng, 1993). There were insufficient animals in stages A and B for statistical analysis, and data of stages $C$ and $\mathrm{D}_{0}$ were pooled.

Physiological states of male and female shrimp were compared. No differences were observed between male and female ( $p>0.35$ for all parameters). Data were therefore grouped.

Data were analysed with ANOVA at the significant threshold of 5\% (Statview computer software). Data are expressed and plotted as mean \pm standard error.

\section{Results}

\subsection{Sediment and water characteristics}

\section{Water}

Mean temperature was $27.6^{\circ} \mathrm{C}$, salinity $27 \%$ and osmotic pressure $777 \mathrm{mOsm} \mathrm{kg}^{-1}$. Mean early morning dissolved oxygen concentrations varied between 3.6 and $4.9 \mathrm{mg}^{-1}{ }^{-1}$ with an average of $4.2 \pm 0.6 \mathrm{mg} . \mathrm{l}^{-1}$. Mean $\mathrm{pH}$ was $7.93 \pm 0.04$. Two groups of turbidity could be distinguished: the first one with a mean turbidity of $6.2 \pm 1.5$ NTU corresponding to stations $0,1,2$ and 3 , and the second one with a mean value 3 times higher of $18.9 \pm 0.3$ for stations 4 , 5 and 6. Concentrations of TAN were all below the detection limit of the assay $\left(0.003 \mathrm{mg} . \mathrm{l}^{-1}\right)$. Values of $\mathrm{N}-\mathrm{NO}_{2}$ concentrations varied between 0.36 and $1.37 \mu \mathrm{g} . \mathrm{l}^{-1}$.

\section{Sediment (Table 1)}

The percentage of water in the sediment varied from $24 \%$ (station 1) to $49 \%$ (station 4), with an average of $39 \pm 9 \%$. $\mathrm{pH}$ was nearly homogeneous with a mean value of $7.4 \pm 0.2$. Mean Eh was $117 \pm 17 \mathrm{mV}$. TAN varied between 4.04 and $4.88 \mathrm{mg} \mathrm{l}^{-1}$ for all stations except for station 4 with a value nearly twice as concentrated $\left(8.51 \mathrm{mg} \mathrm{l}^{-1}\right)$. Concentrations of $\mathrm{N}-\mathrm{NH}_{3}$ were all below $0.2 \mathrm{mg} . \mathrm{l}^{-1}$, with an average of $0.08 \pm 0.03 \mathrm{mg} \mathrm{l^{-1 }}$. Average $\mathrm{N}-\mathrm{NO}_{2}$ concentration was as low as $0.04 \pm 0.01 \mu \mathrm{g} \mathrm{l}^{-1}$.

\subsection{Effect of cage confinement (Table 2)}


Recovery of shrimp in cages without contact with pond bottom was 80\%, without dead shrimp being observed the day of sampling. No data were available for control shrimp in stage $\mathrm{D}_{1}$. Hypo-OC (stage $\mathrm{D}_{2}$ only), Mg ions and glucose concentrations in shrimp maintained in cages without contact with soil for $48 \mathrm{~h}$ were not different from the concentrations measured in free control shrimp caught in the pond. However, total proteins and oxyhaemocyanin concentrations were 12.3 to $18.3 \%$ lower in shrimp maintained in cages, for both stages $\mathrm{C} / \mathrm{D}_{0}$ and $\mathrm{D}_{2}$.

\subsection{Effect of exposure to pond bottom on haemolymph constituents}

Mean recovery of shrimp was $87 \%$ and there were no differences in survival between stations, including station 0 (control cages). Location (all molt stages combined) had a highly significant effect on all physiological parameters tested $(\mathrm{p}<0.0001)$.

Not enough data on hypo-OC from control shrimp were available for statistical analysis $(n=2)$ for stage $C / \mathrm{D}_{0}$. However, hypo-OC was lower in shrimp sampled in station 4 compared to animals sampled in the other stations (figure 2A). No differences were observed in this group for $\mathrm{Mg}$ ion concentration, except for station 4 with a value nearly 5 times higher than that of the control (31.6 $\pm 1.7 \mathrm{mmol} \mathrm{l}^{-1}$ against $6.6 \pm 1.9 \mathrm{mmol} \mathrm{l}^{-1}$ for control) (figure 2B). Plasma glucose level was significantly higher in animals located on station 4 (2.4 times the control value), 1 and 6 (1.6 times) compared to control shrimp (figure 2C). Total proteins concentration was also higher in animals of station 4 compared to the control (Figure 3A). There was no significant difference in oxyhaemocyanin concentration, although the concentration observed in shrimp from station 2 tended to be lower than in control shrimp $(\mathrm{p}=0.051)$ (Figure 3B). Lastly for this group, the ratio oxyhaemocyanin/total proteins was significantly lower in shrimp from stations 2 (60\% of the control value) and 4 (70\%) compared to the control (Figure 3C).

Hypo-OC was depressed in animals in stage $\mathrm{D}_{1}$ located on station 4 (2.3 times lower than that of the control), but also on station 3 (1.5 times lower) compared to the control (Figure 2A), while $\mathrm{Mg}$ ions concentration was 3.7 times higher on station 4 than for control shrimp, reaching $35.9 \pm 2.1 \mathrm{mmol} \mathrm{l}^{-1}$. Mg ions were also significantly higher in station 1 (14.2 \pm 1.8 mmol $\left.{ }^{-1}\right)$ compared to the control $\left(9.7 \pm 1.2 \mathrm{mmol} \mathrm{l}^{-1}\right)$ (Figure $\left.2 \mathrm{~B}\right)$. As for stage $\mathrm{C} / \mathrm{D}_{0}$, plasmatic glucose concentration was increased in shrimp of station $4\left(103.7 \pm 12.8 \mathrm{mg} \mathrm{dl}^{-1}\right)$ compared to control (39.2 $\pm 2.0 \mathrm{mg} \mathrm{dl}^{-1}$ ), and also in shrimp of stations 1, 2 and 6 (Figure 2C). Total proteins concentration was significantly lower in shrimp from stations 1, 3, 5 and 6 
compared to control, while concentration was close to the control $\left(156.9 \pm 5.5 \mathrm{mg} \mathrm{dl}^{-1}\right)$ for stations 2 and 4 (respectively $158.7 \pm 3.5$ and $165.6 \pm 5.7 \mathrm{mg} \mathrm{ml}^{-1}$ ) (Figure 3A). Oxyhaemocyanin concentration was also lower in all stations compared to control except in stations 4 and 5 (Figure 3B). The ratio oxyhaemocyanin/total proteins was reduced of 30\% compared to the control for shrimp in station 2, while there were no differences for the other stations (Figure 3C).

Exposure to sediment had an effect on all physiological parameters for shrimp in stage $\mathrm{D}_{2}$, except on total proteins concentration ( $>00.05$ ) (Figures 2 and 3). Hypo-OC of shrimp in station 4 was significantly lower compared to control (+17.5 \pm 4.7 against $-16.5 \pm 5.3$ mOsm $\mathrm{kg}^{-1}$ ) (Figure 2A). Mg ion concentration of shrimp sampled on station 4 was 4 times higher than control (30.9 \pm 2.1 against $7.6 \pm 1.0 \mathrm{mmol}^{-1}$ ) (Figure $2 \mathrm{~B}$ ). Glucose level was higher in 4 stations out of 6 compared to control (Figure 2C), with a maximum value of $79.2 \pm 4.9 \mathrm{mg} \mathrm{dl}^{-}$ ${ }^{1}$ in station 4 (Figure 2C). As for stage $D_{1}$, oxyhaemocyanin was lower in 5 stations out of 6 , with a maximum decrease for station $4\left(1.52 \pm 0.08 \mathrm{mmol} \mathrm{l}^{-1}\right.$ compared to $2.03 \pm 0.07 \mathrm{mmol} \mathrm{l}^{-}$ ${ }^{1}$ for control) (Figure 3B). The ratio oxyhaemocyanin/total proteins was significantly lower for station 2 and 4 compared to control (Figure 3C).

\subsection{Effect of molt stage}

The only difference for control shrimp (no stage $\mathrm{D}_{1}$ ) is a lower total proteins concentration in stage $C / D_{0}$ compared to $D_{2}$ (table 2 ). All stations mixed, only oxyhaemocyanin concentration was affected by molt stage $(\mathrm{p}=0.04)$. If we look at the different locations within the pond, some differences appeared for stations 4 and 5. In station 4, oxyhaemocyanin concentration was lower in stage $D_{2}$ compared to stages $D_{1}$ and $C / D_{0}$, and stage $C / D_{0}$ was also significantly lower than stage $D_{1}$ (figure $3 B$ ). Total proteins concentration was higher in stage $C / D_{0}$ compared to stages $\mathrm{D}_{1}$ and $\mathrm{D}_{2}$ (figure $3 \mathrm{~A}$ ), while the ratio oxyhaemocyanin/total proteins was lower in stages $C / D_{0}$ and $D_{2}$ compared to stage $D_{1}$ (figure $3 C$ ). The hypo-OC was lower in stage $\mathrm{D}_{2}$ compared to stage $C / \mathrm{D}_{0}$ in station 5 (figure $2 \mathrm{~A}$ ).

\section{Discussion}

\subsection{Effect of cage confinement}


The lack of significant decrease in hypo-OC and increase in Mg ions, glucose, total proteins and oxyhaemocyanin in both intermolt and premolt animals indicates that the shrimp confined in cage presented no sign of short-term stress response (Lignot et al., 2000; Hall and Vanham, 1998, Boglio and Goarant, 1996, Mugnier and Justou, 2004). Decrease in total proteins was mainly due to the decrease in haemocyanin, as the ratio oxyhaemocyanin/total proteins in confined shrimp was close to the value observed in control animals. Shrimp in cages received presumably less food than the free shrimp in the pond, as they were not specifically fed. Therefore, partial starvation could be the origin of the lower concentration in plasmatic total proteins.

\subsection{Water and sediment characteristics}

Water chemistry values were homogenous within the pond, indicating a good circulation of water, and were also within a correct range for shrimp rearing (Boyd, 1990). Salinity (27\%o) was lower than that observed usually in ponds in New Caledonia (around 34-35\%o), due to a tropical depression and heavy rain the days preceding the experiment. However, it was the same throughout the $48 \mathrm{~h}$ of experiment. The osmotic pressure of the water $\left(777 \mathrm{mOsm} \mathrm{kg}{ }^{-1}\right.$ )

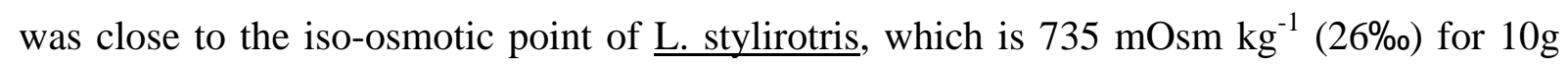
shrimp (Lemaire et al., 2002). Oxygen concentrations were all above the level of $3 \mathrm{mg} \mathrm{l}^{-1}$, below which long-term effect on survival and growth is observed in L. stylirostris (Aquacop et al., 1988) and short-term effect on hypo-OC (Mugnier and Soyez, 2005).

Sediment of station 4, located in the middle of the pond, was characterized by the highest water content, corresponding to the lowest bulk density (Avnimelech et al., 2001). Although there is no direct measure of organic matter, it has been shown that the bulk density is inversely related to the organic carbon concentration (Avnimelech et al., 2001; unpublished data). Concentration of TAN in pore water, which is mainly the product of organic matter mineralization, was also higher in station 4 than in the other stations. These indicators suggest that it was the main zone of deposited organic matter.

\subsection{Shrimp physiological response in relation to pond bottom}

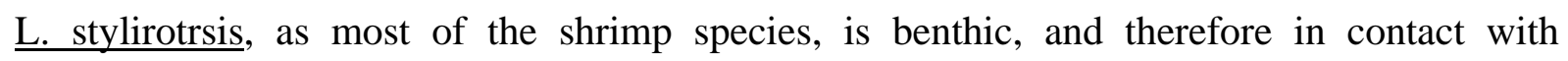
sediment and exposed to its compounds and those of pore water (Lemonnier et al., 2004). 
A decrease in hypo-OC coupled with an increase in $\mathrm{Mg}$ ion and glucose concentrations in shrimp sampled in station 4 -whatever the molt stage- compared to control shrimp (station 0) are characteristic of a short-term stress response. Moreover, the ratio oxyhaemocyanin/total proteins was significantly decreased in stages $C / D_{0}$ and $D_{2}$. In a less extend, shrimp sampled in station 1 presented a stress response limited to an increase in glucose concentration in the three molt stages, coupled with an increase in $\mathrm{Mg}$ ion concentration in stage $\mathrm{D}_{1}$ only. Station 2 seemed also to induce a stress response which was not observed in stage $C / D_{0}$, except a decrease in ratio oxyhaemocyanin/total proteins. Previous works have shown that zones of organic matter accumulation can result in lower shrimp abundance and reduced shrimp growth (Delgado et al, 2003; Ritvo et al., 1998). However, even if station 4 was presumably the main zone of deposited organic matter, measured indicators of water and sediment pore water quality were within normal operating limits. No stressors could be identified. Therefore, no conclusion could be deduced from the present results about the nature of the stressor(s). However, synergic effects of two sub-lethal parameters such as oxygen and $\mathrm{NH}_{3}$ on survival have been observed in experimental conditions (Allan et al., 1990, Wajsbrot et al., 1990; unpublished results), and nothing is known on a possible cumulative effects of environmental factors at sub-stressful concentrations on shrimp physiology.

\subsection{Effect of molt stage}

Comparison of stage $C / D_{0}$ and $D_{2}$ in the control group showed that, as previously observed in $\underline{L}$. stylirostris, there were no significant differences in Mg ion concentration, glucose and ratio oxyhaemocyanin/proteins (Mugnier and Justou, 2004). The lowest hypo-OC usually observed in stage $\mathrm{D}_{2}$ compared to stage C (Lignot et al., 1999; Mugnier and Justou, 2004) was not observed in our study, but the osmotic pressure of the water close to the iso-osmotic point of the haemolymph means that the need of osmotic regulation was reduced and possibly within the capacity of $\mathrm{D}_{2}$ animals. Oxyhaemocyanin and total proteins concentrations were significantly higher in stage $\mathrm{D}_{2}$ compared to stage $C / \mathrm{D}_{0}$. A similar tendency was observed in a previous study (Mugnier and Justou, 2004).

In term of stress response, stage $D_{1}$ seems to be more sensitive than stages $D_{2}$ and $C / D_{0}$ as shown by a significant increase in plasmatic glucose concentration in 4 stations out of 6 (only 3 stations for stage $C / D_{0}$ ) and in $\mathrm{Mg}$ ion in two station out of 6 (one station for stages $C / \mathrm{D}_{0}$ and $\mathrm{D}_{2}$ ) compared to the control, and also a decrease in total proteins and oxyhaemocyanin in 4 stations out of 6 . 


\subsection{Physiological parameters as tools to evaluate environmental conditions in the field}

Variation in all parameters was similar to what was observed in $\underline{L}$. stylirostris subjected to a stressful concentration of ammonia, except for total proteins which was decreasing in stressed animals compared to control (Mugnier and Justou, 2004). Because oxyhaemocyanin did not change, the ratio oxyhaemoncyanin /total proteins was decreased for stage $\mathrm{C}$, while the decrease in ratio was mainly due to oxyhaemocyanin decrease in stage $\mathrm{D}_{2}$.

OC, which is usually a sensitive stress indicator in osmoregulator species (Lignot et al., 2000), showed its limit in this field survey. Indeed, due to the low salinity and therefore osmolality of the pond water, with a value close to the iso-osmotic point of the shrimp, OC response was moderate. Lignot et al. (1999) encountered the same type of problem with a field experiment where salinity varied throughout their experiment. They could not use the osmoregulatory capacity as a stress indicator (Lignot et al., 1999), but used the osmolality instead. However, the OC is still a good indicator if salinity conditions are the same throughout the sampling. For example, Lemonnier et al. (2004) were able to use OC to indicate stress from $\mathrm{pH}$ on shrimp.

Blood glucose level seems to be the more sensitive physiological parameter in this study. Hall and Van Ham (1998) observed that increase of blood glucose occurred when $\underline{\text { P. monodon was }}$ submitted to stressors such as depletion of dissolved oxygen or increase dissolved carbon dioxide levels, perturbation which may be encountered in a pond. The second more sensitive indicator is $\mathrm{Mg}$ ion concentration, which plays an important role as co-factor in enzyme systems and as a modulator of the haemocyanin (Morrit and Spicer, 1993). Boglio and Goarant (1996) found that this stress indicator was more sensitive than osmolality for $\underline{P}$.

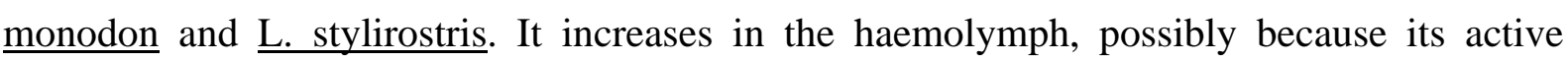
regulation is compromised as a result of stress. Total proteins concentration presents a controversial pattern in molt stage $\mathrm{D}_{1}$ : it was equivalent to the control in shrimp of station 4 showing furthermore a stress response (decrease in hypo-OC, increase in $\mathrm{Mg}$ ion and glucose concentrations), but was also significantly lower in shrimp with no sign of stress such as in station 5. It increased in shrimp in stage $\mathrm{C}$ in station 4 compared to the control cages and suggests that the increase rather than the decrease was part of the stress response. It was therefore a poor indicator in this study. Oxyhaemocyanin was also significantly lower in most of the stations compared to control cages for both $\mathrm{D}_{1}$ and $\mathrm{D}_{2}$. Thus, the ratio oxyhaemocyanin/total proteins is possibly more representative of a stress response (station 4 
and 2 for stages $C$ and $D_{2}$, station 2 for stage $D_{1}$ ), and therefore more relevant than total proteins or oxyhaemocyanin separately.

The technique used in this study to evaluate environmental conditions in the field for their impact on shrimp has good potential for producing useful information.

\section{Aknowledgements}

This work was supported by research grants from the North and South Provinces of New Caledonia. The authors would like to thank the owner of the private farm and his employees to allow us to access to the farm facilities and the shrimp, and permit this experiment to be conducted in good conditions. We also want to thank the people of the Laboratoire d'Aquaculture Calédonien who kindly helped for the sampling.

\section{References}

Aquacop, Bédier, E., Soyez, C., 1988. Effects of dissolved oxygen concentration on survival and growth of Penaeus vannamei and Penaeus stylirostris. J. World Aquac. Soc. 19, 13A.

Avnimelech, Y., Ritvo, G., Meijer, L.E., Kochba, M, 2001. Water content, organic carbon and dry bulk density in flooded sediments. Aquacultural Engineering 25: 25-33.

Avnimelech, Y., Zohar, G., 1986. The effect of local anaerobic conditions on growth retardation in aquaculture systems. Aquaculture 58, 167- 174.

Benschneider, K., Robinson, R.J., 1952. A new spectrophotometric method for the determination of nitrite in seawater. J. Mar. Res. 11, 86 - 87.

Boglio, E., Goarant, C., 1996. Hemolymph magnesium as a measure of acute physiological stress in wild broodstock Penaeus monodon and cultured broodstock $\underline{\text { P. stylirostris. In }}$ “Second International Conference on the Culture of Penaeid Prawns and shrimp”, pp. 101, Iloilo, Philippines.

Bower C.E., Bidwell J.P., 1978. Ionization of ammonia in seawater: effects of temperature, pH and salinity. J. Fish. Res. Board Can. 35, 1012-16.

Boyd, C.E., 1990. Water quality in ponds for aquaculture. Alabama Agricultural Experimental Station, Auburn University, Alabama, USA. 
Boyd, C.E., 1995. Bottom soils, sediment and pond aquaculture. Chapman and Hall, New York, USA. pp 348.

Chan, S.-M., Rankin, S. M., Keeley, L. L., 1988. Characterization of the molt stages in Penaeus vannamei: setogenesis and hemolymph levels of total protein, ecdysteroids, and glucose. Bio. Bull. 175, 185-192.

Chen J.-C. Cheng S.-Y., 1993. Studies on haemocyanin and haemolymph protein levels of Penaeus japonicus based on sex, size and moulting cycle. Comp. Biochem. Physiol. 106B(2), 293-296.

Delgado, P.C., Avnimelech, Y., McNeil, R., Bratvold, D., Browdy, C.L., Sandifer, P., 2003. Physical, chemical and biological characteristics of distinctive regions in paddlewheel aerated ponds. Aquaculture 217, 235-248.

Drach P., 1939. Mue et cycle d’intermue chez les crustacés décapodes. Annales de l’Institut Océanographique de Paris N. S. 19, 103-391.

Hall, M. R., VanHam, E. H., 1998. The effects of different types of stress on blood glucose in the giant tiger prawn Penaeus monodon. J. World Aquac. Soc. 29, 290-299.

Hopkins, J.S., Sandifer, P.A., Browdy, C.L., 1994. Sludge management in intensive pond culture of shrimp: effect of management regime on water quality, sludge characteristic, nitrogen extinction, and shrimp production. Aquacultural Engineering 13, 11-30.

Hussenot, J., Martin, J.L.M., 1995. Assessment of the quality of pond sediment in aquaculture using simple rapid techniques. Aquaculture International 3, 123-133.

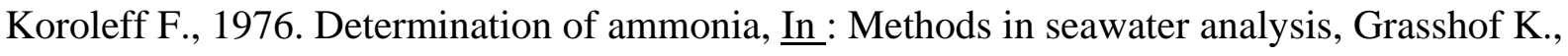
Eds. Verlag Chimie, Weineim, RFA, 126-133.

Lemaire, P., Bernard, E., Martinez-Paz, J.A., Chim, L., 2002. Combined effect of temperature and salinity on osmoregulation of juvenile and subadult Penaeus stylirostris. Aquaculture 209, 307-317.

Lemonnier, H., Brizard, R., 2001. Evolution of pond bottom and production in a semiintensive shrimp pond. World Aquaculture Society meeting, January 21-25, 2001, Disney’s Coronado Springs Resort Lake Buena Vista, Forida. Boork of Abstracts, p. 366.

Lemonnier, H., Bernard, E., Boglio, E., Goarant, C., Cochard, J.C., 2004. Influence of sediment characteristics on shrimp physiology: $\mathrm{pH}$ as principal effect. Aquaculture 240, 297-312.

Lignot J.-H., Cochard J.-C., Soyez C., Lemaire P., Charmantier G., 1999. Osmoregulatory capacity according to nutritional status, molt stage and body weight in Penaeus stylirostris. Aquaculture 170, 79-92. 
Lignot, J.H., Spanings-Pierrot, C., Charmantier, G., 2000. Osmoregulatory capacity as a tool in monitoring the physiological condition and the effect of stress in crustaceans. Aquaculture 191, 209-245.

Lowry O.H., Rosebrough N.F., Farr A.L., Randall R.J., 1951. Protein measurement with the Folin phenol reagent. J. Biol. Chem. 193, 251.

Morritt, D., Spicer, J. I., 1993. A brief re-examination of the function and regulation of extracellular magnesium and its relationship to activity in crustacean arthropods. Comparative Biochemistry and Physiology 106A, 19-23.

Mugnier, C., Justou, C., 2004. Combined effect of external ammonia and molt stage on the blue shrimp Litopenaeus stylirostris physiological response. J. Exp. Mar. Biol. Ecol. 309, $35-46$.

Mugnier, C., Soyez, C., 2005. Response of the blue shrimp Litopenaeus stylirostris to temperature decrease and hypoxia in relation to molt stage. Aquaculture 244, 315-322..

Paul, R. J., Pirow, R., 1997/98. The physiological significance of respiratory proteins in invertebrates. Zoology 100, 298-306.

Péqueux A., 1995. Osmotic regulation in crustaceans. Journal of crustacean biology 15, 1-60.

Ram, N.M., Zur, O., Avnimelech, Y, 1982. Microbial changes occurring at the sedimentwater interface in an intensively stocked and fed fish pond. Aquaculture 27, 63-72.

Ritvo, G., Samocha, T.M., Lawrence, A.L., Neill, W.H., 1998. Growth of Penaeus vannamei on soils from various Texas shrimp farms, under laboratory conditions. Aquaculture 163, 101-110.

Wajsbrot, N., Gasith, A., Krom, M.D., Samocha T.M., 1990. Effect of dissolved oxygen and the molt stage on the acute toxicity of ammonia to juvenile green tiger prawn Penaeus semisulcatus. Environmental Toxicology and Chemistry 9, 497-504. 
Table 1. : Values of sediment parameters for each station. Refer to figure 1 for location of stations within the pond.

\begin{tabular}{lcccccc}
\hline & \multicolumn{7}{c}{ Stations } \\
\cline { 2 - 7 } & 1 & 2 & 3 & 4 & 5 & 6 \\
\hline Water content (\%) & 24 & 37 & 39 & 49 & 44 & 38 \\
$\mathrm{pH}$ & 7.5 & 7.1 & 7.3 & 7.3 & 7.3 & 7.5 \\
Redox potential (mV) & 151 & 108 & 112 & 111 & 107 & 111 \\
Total ammonia N (mg l $\left.{ }^{-1}\right)$ & 4.88 & 4.69 & 5.03 & 8.51 & 4.04 & 4.52 \\
$\mathrm{NH}_{3}-\mathrm{N}\left(\mathrm{mg} \mathrm{l}^{-1}\right)$ & 0.11 & 0.04 & 0.07 & 0.13 & 0.06 & 0.09 \\
$\mathrm{NO}_{2}$-N $\left(\mu \mathrm{g} \mathrm{l}^{-1}\right.$ ) & 0.03 & 0.03 & 0.03 & 0.05 & 0.05 & 0.03 \\
\hline
\end{tabular}




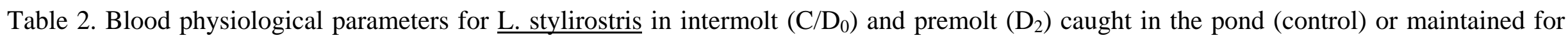
48h in cages; Mean \pm S.E. (n).

\begin{tabular}{|c|c|c|c|c|}
\hline & \multicolumn{2}{|c|}{ Intermolt } & \multicolumn{2}{|c|}{ Premolt (Stage D2) } \\
\hline & Control (19) & Cage (3) & Control & Cage \\
\hline Нуро-OC (mOsm kg $\left.{ }^{-1}\right)$ & $-33.4 \pm 3.9$ & - & $-28.6 \pm 5.5(18)$ & $-17.4 \pm 4.7(13)$ \\
\hline Mg ions (mmol l-1) & $7.96 \pm 0.60$ & $6.59 \pm 1.92$ & $5.83 \pm 1.25(16)$ & $7.60 \pm 0.99(13)$ \\
\hline Glucose (mg dl ${ }^{-1}$ ) & $55.8 \pm 3.3$ & $39.3 \pm 8.3$ & $48.9 \pm 2.7(15)$ & $41.4 \pm 3.7(13)$ \\
\hline Total proteins (mg ml $\mathrm{m}^{-1}$ ) & $160.8 \pm 4.1^{\mathrm{a}}$ & $135.1 \pm 13.0^{*}$ & $172.4 \pm 2.7^{\mathrm{b}}(15)$ & $151.1 \pm 5.4(13)^{*}$ \\
\hline Oxyhaemocyanin $\left(\mathrm{mmol} \mathrm{l}^{-1}\right)$ & $2.19 \pm 0.06$ & $1.79 \pm 0.19 *$ & $2.42 \pm 0.10(16)$ & $2.03 \pm 0.07(13)^{*}$ \\
\hline Oxyhaemocyanin/total proteins ratio (\%) & $90.7 \pm 2.7$ & $87.1 \pm 1.2$ & $92.6 \pm 3.6(15)$ & $90.5 \pm 5.4(13)$ \\
\hline
\end{tabular}

* Significant difference between control and animals in cage for each molt stage $(\mathrm{P}<0.05)$.

Significant differences between molt stages for control shrimp are indicated by different letters $(\mathrm{P}<0.05)$ 


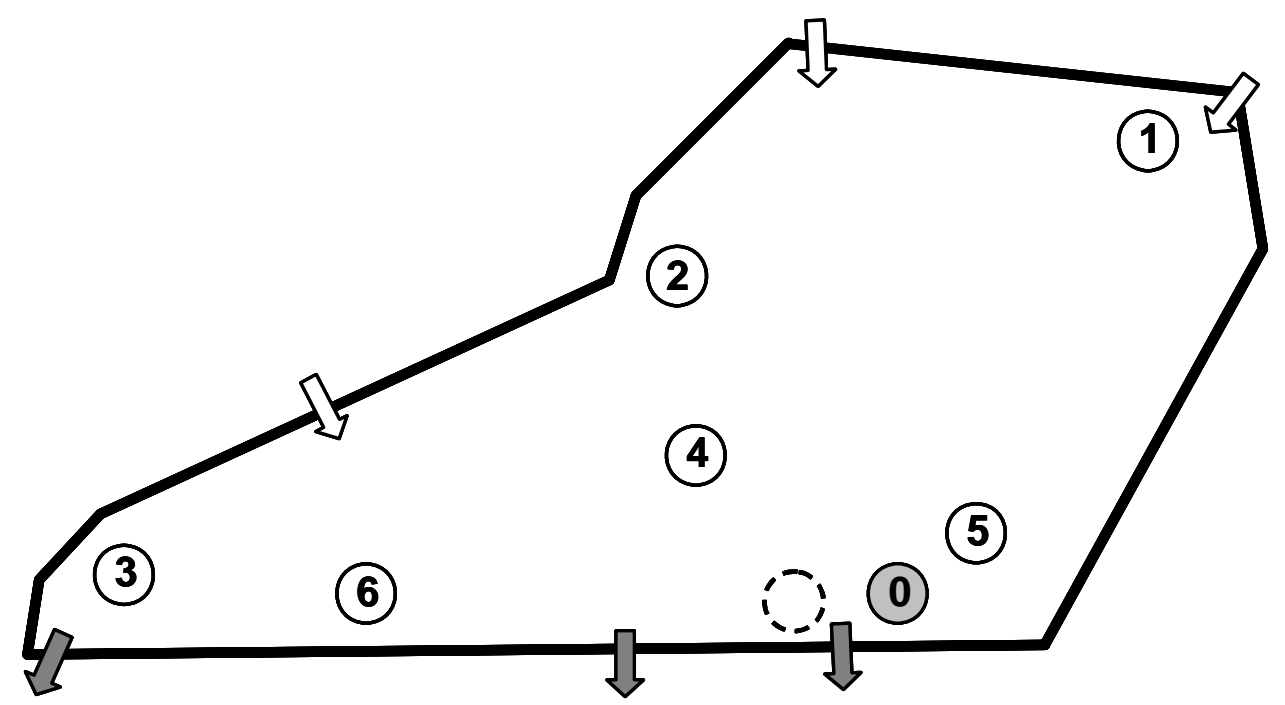

$\bigcirc$ Stations

$\bigoplus$ Water inlet

$\bigcirc$ Control cages

' Sampling of free animals

$₫$ Water outlet

Figure 1: Schematic representation of the pond and location of the stations. Three cages per station. 

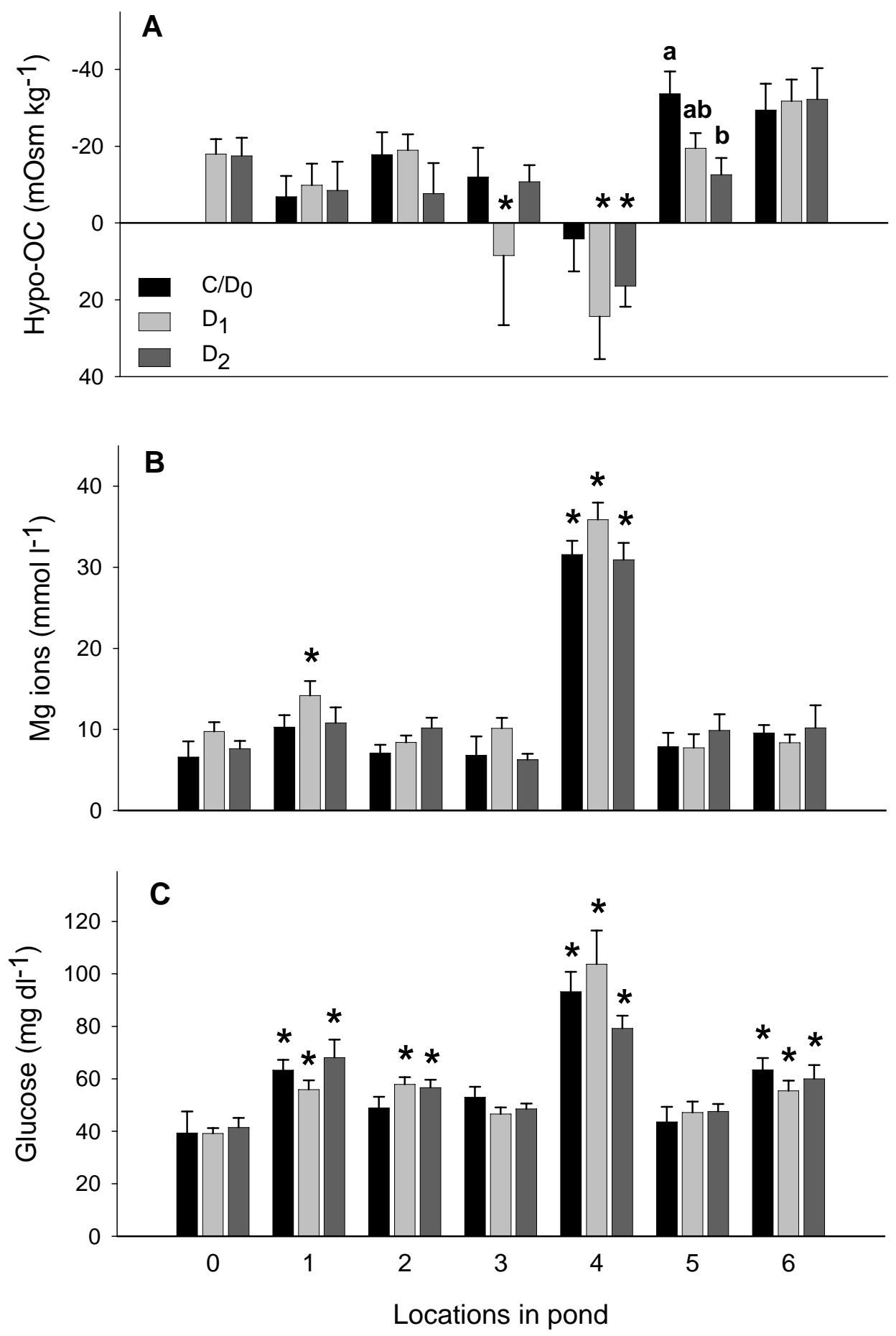

Figure 2. Mean (S.E.) hypo-osmoregulatory capacity (hypo-OC) (A), Mg ion concentration

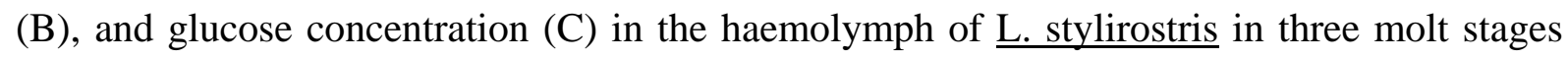
$\left(C / D_{0}, D_{1}\right.$ and $\left.D_{2}\right)$ maintained in cages above the soil (control, 0$)$ or in contact with sediment (1 to 6 ) for $48 \mathrm{~h}$. See figure 1 for location of stations within the pond. Mean values from 3-19 determinations.

For each molt stage, bars with * are significantly different from control $(\mathrm{p}<0.05)$. 
Within a location, bars with different letters indicate significant differences between molt stages $(\mathrm{p}<0.05)$. 

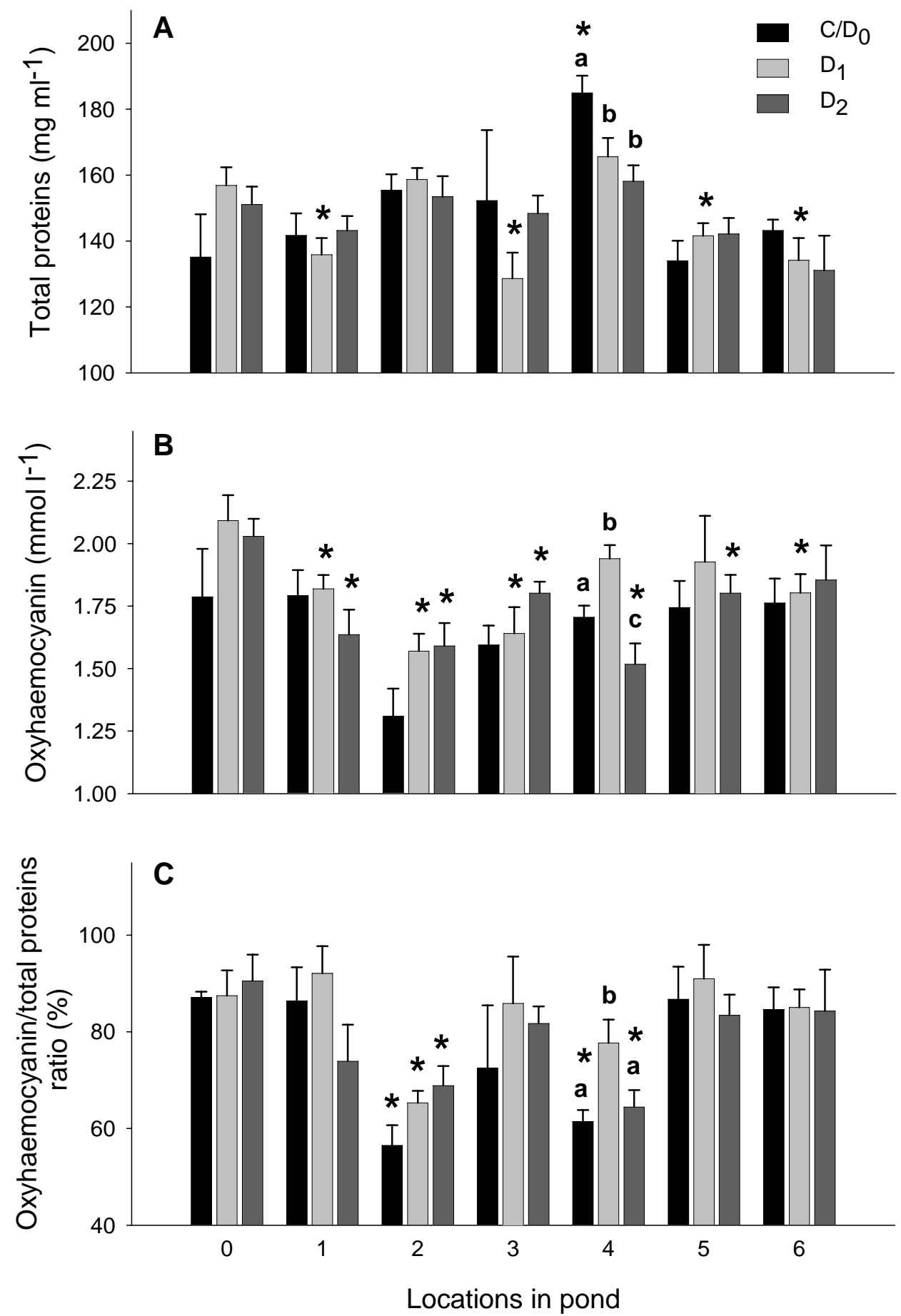

Figure 3. Mean (S.E.) total proteins (A), oxyhaemocyanin (B) concentrations and

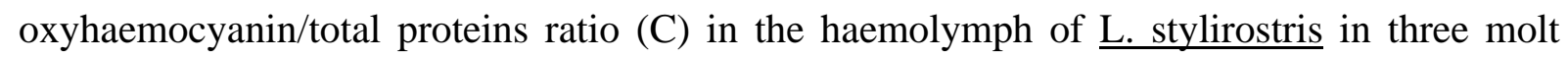
stages $\left(C / D_{0}, D_{1}\right.$ and $\left.D_{2}\right)$ maintained in cages above the soil (control, 0$)$ or in contact with sediment (1 to 6 ) for $48 \mathrm{~h}$. See figure 1 for location of stations within the pond. Mean values from 3-19 determinations.

For each molt stage, bars with * are significantly different from control $(\mathrm{p}<0.05)$. 
Within a location, bars with different letters indicate significant differences between molt stages $(\mathrm{p}<0.05)$. 